\title{
PENGEMBANGAN MEDIA PEMBELAJARAN MATEMATIKA BERBASIS GEOGEBRA DENGAN PENDEKATAN TEORI VAN HIELE PADA POKOK BAHASAN NILAI MAKSIMUM DAN MINIMUM
}

\author{
I G. D. Kurniawan, I M. Sugiarta, G. Suweken \\ Program Studi S1 Pendidikan Matematika \\ Universitas Pendidikan Ganesha \\ Singaraja, Indonesia \\ e-mail: igedededikurniawan222@gmail.com, gdsuweken5@gmail.com, madesugiarta54@gmail.com
}

\begin{abstract}
Abstrak
Penelitian ini adalah penelitian pengembangan yang bertujuan untuk menghasilkan produk media pembelajaran matematika berbasis Geogebra dengan pendekatan teori van Hiele pada pokok bahasan nilai maksimum dan minimum. Model pengembangan yang digunakan adalah Model 4-D (define, design, develop, disseminate) tetapi hanya dilaksanakan hingga tahap 3 (develop).Teknik anaisis data yang digunakan adalah teknik analisis data deskriptif kualitatif dan kuantitatif. Penelitian dilaksanakan di SMA Negeri 2 Negara dengan melibatkan 9 orang sebagai peserta uji coba. Terdapat tiga aspek yang dikaji dalam pengembangan media pembelajaran ini, yaitu: (1) kevalidan, (2) kepraktisan, dan (3) keefektifan. Hasil penelitian menunjukkan bahwa rata-rata skor dari ahli media pembelajaran adalah 4,67(sangat tinggi), oleh pengajar adalah 4,30 (sangat tinggi), persentase kepraktisan oleh guru $97,75 \%$ (sangat tinggi),persentase kepraktisan siswa sebesar $90 \%$ (sangat tinggi), dan hasil tes efektifitas media pembelajaran adalah $88,89 \%$.Berdasarkan hasil uji coba tersebut media yang dikembangkan memenuhi kriteria valid, praktis, dan efektif dalam pokok bahasan nilai maksimum dan minimum.
\end{abstract}

KataKunci:Geogebra, Maksimum, Media, Minimum, Teori van Hiele

\begin{abstract}
This research is a development research that aimed to produce Geogebra-based mathematics learning media based on the van Hiele learning theory, subject of maximum and minimum values. The development model used is the 4-D Model (define, design, develop, disseminate) but the model is only execated up to the third stage (i.e. development stage). Data analysis used are qualitative and quantitative descriptive data analysis techniques. The study was conducted in SMA N 2 Negara involving 9 people as trial participants. There are three aspects studied in the development of this learning media, namely: (1) validity, (2) practicality, and (3) effectiveness. The results showed that the average score of the learning media expert is 4.67 (very high), by the teacher is 4.30 (very high), the percentage of practicality by the teacher is $97.75 \%$ (very high), the percentage of student practicality is $90 \%$ (very high), and the results of the learning media effectiveness test are $88.89 \%$. Based on the results of the trial, the developed media meets the criteria of validity, practicality, and effectiveness in the subject matter of maximum and minimum values.
\end{abstract}

Keywords: Geogebra, Maxsimum, Media, Minimum, van Hiele Theory

\section{Pendahuluan}

Pemahaman konsep merupakan faktor penting yang harus diperhatikan dalam kegiatan pembelajaran, khususnya pada pembelajaran matematika yang penuh dengan rumus. Kecendrungan siswa untuk menghafal rumus matematika yang sangat banyak daripada memahami konsepnya, akan menimbulkan kebingungan bagi siswa itu sendiri. Pemahaman konsep dalam hal ini akan sangat membantu siswa untuk dapat mempelajari matematika dengan lebih efektif.

Nilai maksimum dan minimum adalah salah satu pokok bahasan dalam pembelajaran matematika khususnya yang berkaitan dengan penerapan turunan fungsi aljabar yang

Jurnal Pendidikan dan Pembelajaran Matematika Indonesia | 122 
diajarkan di kelas XI SMA. Berdasarkan hasil wawancara yang dilakukan terhadap dua orang guru matematika di SMA Negeri 2 Negara, diketahui bahwa dalam kegiatan pembelajaran di kelas pemahaman mengenai konsep nilai maksimum dan minimum ini sering diabaikan oleh siswa. Hal ini dikarenakan kesulitan siswa dalam membayangkan pernyataan yang disampaikan dalam materi ini. Oleh karenanya, siswa lebih cenderung untuk menghafal daripada memahami maksud dari konsep-konsep yang ada.

Menurut pendapat beberapa siswa kelas XII SMA Negeri 2 Negara yang telah mempelajari tentang nilai maksimum dan minimum, dikatakan bahwa materi ini sangat sulit untuk dipahami. Siswa juga kesulitan ketika membayangkan konsep limit yang muncul ketika menentukan kemiringan garis singgung dan mengapa nilai maksimum dan minimum dapat terjadi pada titik ujung, titik stasioner, ataupun titik singular suatu fungsi objektif. Penjelasan mengenai materi tersebut sudah disampaikan oleh guru,akan tetapi hanya terbatas pada penjelasan secara lisan atau dengan menggunakan media papan tulis, buku, modul, dan slide Power Point saja. Materi pembelajaran yang padat juga menjadi kendala, sehingga guru tidak dapat menjelaskan secara berulang-ulang hingga seluruh siswa dapat memahami pembelajaran yang diberikan. Tentu saja masalah ini menjadi sebuah permasalahan yang besar mengingat bahwa kecepatan belajar setiap siswa yang berbeda-beda. Cara paling mudah dalam memahami konsep nilai maksimum danm minimum adalah dengan menggunakan grafik dan pendekatan kemiringan garis singgung yang dapat dieksplorasi siswa. Akan tetapi, tidak adanya media yang mendukung siswa untuk dapat bereksplorasi di sekolah menyulitkan guru dalam memberikan pemahaman dengan cara tersebut.

Penggunaan media di sekolah yang masing tergolong jarang dan terbatas dalam penggunaan slide Power Point saja, tentu masih kurang efektif bagi siswa, karena sebagian besar masih berupa materi saja. Penggunaan media yang terbatas pada slide Power Point, membuat pembelajaran cenderung monoton dan kurang bervariasi, sehingga keterlibatan siswa dalam proses pembelajaran belum optimal. Kesulitan guru untuk mendapatkan media pembelajaran nilai maksimum dan minimum, juga menjadi permasalahan bagi guru dalam meningkatkan kualitas pembelajaran.

Penggunaan media pembelajaran berbasis teknologi informasi (TI) dapat menjadi salah satu solusi dari kesulitan siswa dalam memahami konsep nilai maksimum dan minimum. Salah satu software open source yang dapat digunakan untuk mengembangkan sebuah media pembelajaran nilai maksimum dan minimum berbasis $\mathrm{TI}$ adalah software Geogebra.Geogebra dikembangkan oleh Markus Hohenwarter pada tahun 2001. Menurut Hohenwarter (2008), Geogebra adalah software untuk membelajarkan matematika khususnya geometri dan aljabar. Dengan memanfaatkan Geogebra dapat dihasilkan suatu media pembelajaran nilai maksimum dan minimum yang interaktif dan eksploratif sehingga dapat membantu siswa dalam memahami konsep-konsep dalam materi nilai maksimum dan minimum dengan lebih baik.

Untuk dapat mengembangkan media pembelajaran yang baik, menurut Nieveen (1999) terdapat tiga aspek yang harus diperhatikan, yakni: (1) aspek validitas (validity), (2) aspek kepraktisan (practically), dan (3) aspek keefektifan (effectivenness). Untuk dapat mengembangkan media pembelajaran yang valid, praktis, dan efektif menurut Trianto (2012: 189), terdapat beberapa model pengembangan media pembelajaran yang dapat digunakan seperti model 4-D, model Dick dan Caray, dan model Kemp. Salah satu alternatif model pengembangan yang disarankan oleh Thiagarajan pada tahun 1974 adalah model 4-D. Kelebihan dari model 4-D diantaranya adalah: (1) lebih tepat digunakan sebagai dasar untuk mengembangkan perangkat pembelajaran bukan untuk mengembangkan sistem pembelajaran, (2) uraiannya lebih lengkap dan sistematis, (3) dalam pengembangannya melibatkan penilaian ahli, sehingga media pembelajaran telah direvisi berdasarkan penilaian, saran, dan masukan dari para ahli sebelum diuji cobakan.

Menurut Nieveen (1999), aspek validitas (validity) suatu media merupakan salah satu aspek penting dalam mengembangkan sebuah media pembelajaran. Dalam mengembangkan media pembelajaran, pendekatan pembelajaran yang digunakan dalam 
media memegang peran penting untuk mencapai valid. Materi pembelajaran yang dikembangkan dalam media harus disesuaikan dengan pendekatan pembelajaran Kurikulum 2013 yang diterapkan di sekolah saat ini. Pemahaman konsep siswa harus ditingkatkan melalui serangkaian aktivitas pembelajaran yang bisa memberikan pengetahuan dalam diri siswa, seperti menemukan kembali konsep atau bentuk umum. Salah satu teori pembelajaran yang menekankan hal-hal di atas adalah pembelajaran berbasis tahap berpikir van Hiele.

Teori van Hiele yang dikembangkan oleh Pierre Marie van Hiele dan Dina van HieleGeldof sekitar tahun 1950 telah diakui secara internasional dan memberikan pengaruh yang kuat dalam pembelajaran geometri di sekolah (Abdussakir, 2009:3). Menurut teori van Hiele, seseorang akan melalui 5 (lima) tahap perkembangan berpikir van Hiele yaitu tahap 0 (visualisasi), tahap 1 (analisis), tahap 2 (deduksi informal), tahap 3 (deduksi), dan tahap 4 (rigor). Adapun karakteristik yang menjadi kelebihan dari Teori van Hiele, yaitu (1) tahaptahap tersebut bersifat hierarki dan sekuensial, (2) kecepatan berpindah dari tahap ke tahap berikutnya lebih bergantung pada pembelajaran, dan (3) setiap tahap mempunyai kosakata dan sistem relasi sendiri-sendiri. (Anne, 1999).

Berdasarkan uraian di atas, untuk mengatasi kesulitan siswa dalam proses pembelajaran serta membantu guru dalam mengembangkan media pembelajaran matematika yang valid, praktis, dan efektif maka peneliti berencana untuk melakukan penelitian pengembangan media pembelajaran matematika yang berjudul "Pengembangan Media Pembelajaran Matematika Berbasis Geogebra denganPendekatan Teori van Hiele pada Pokok Bahasan Nilai Maksimum dan Minimum".

Berdasarkan latar belakang masalah yang telah dikemukakan di atas, maka fokus masalah dalam penelitian ini adalah bagaimana media pembelajaran matematika yang valid, praktis, dan efektif berbasis Geogebra dengan pendekatan teori van Hiele dalam meningkatkan pemahaman konsep siswa pada pokok bahasan nilai maksimum dan minimum.Adapun tujuan penelitian ini adalah menghasilkan produk media pembelajaran matematika berbasis Geogebra dengan pendekatan teori van Hiele yang valid, praktis, dan efektif dalam meningkatkan pemahaman konsep siswa pada pokok bahasan nilai maksimum dan minimum.

\section{Metode}

Model pengembangan yang digunakan dalam penelitian ini mengikuti alur dari model pengembangan 4-D yang dikembangkan oleh Thiagarajan, dkk. Model ini terdiri atas 4 (empat) tahapan yaitu, define (pendefinisian), design (perancangan), develop (pengembangan), dan disseminate (penyebaran), akantetapi dalam penelitian ini hanya dilaksanakan hingga tahap pengembangan (develop). Penelitian dilaksanakan di SMA Negeri 2 Negara dengan melibatkan 9 orang sebagai peserta uji coba. Terdapat tiga aspek yang dikaji dalam pengembangan media pembelajaran ini, yaitu: (1) kevalidan, (2) kepraktisan, dan (3) keefektifan. Penelitian pengembangan ini menggunakan tiga metode dalam pengumpulan data yaitu: 1) pencatatan dokumen, 2) angket, dan 3) tes. Data analisis rancang bangun media pembelajaran dikumpulkan dengan metode pencatatan dokumen, data uji validasi dan kepraktisan dikumpulkan dengan metode angket, sedangkan untuk data uji efektifitas dikumpulkan dengan metode tes.

Teknik analisis data yang digunakan dalam penelitian ini, yaitu teknik analisis deskriptif kualitatif dan analisis deskriptif kuantitatif.Teknik analisis data deskriptif kualitatif pada penelitian pengembangan ini digunakan untuk mengolah data hasil penilaianahli media pembelajaran, pengajar, guru, dan siswa. Teknik analisis data ini dilakukan dengan mengelompokan informasi-informasi dari data kualitatif yang berupa masukan, tanggapan, kritik, dan saran perbaikan yang terdapat pada angket. Hasil analisis data ini kemudian digunakan untuk merevisi produk yang dikembangkan.Teknik analisis deskriptif kuantitatif pada penelitian ini digunakan untuk mengolah data hasil uji validitas, uji kepraktisan, dan keefektifan media pembelajaran yang dikembangkan.Adapun kriteria yang digunakan dalam 
penilaian kevalidan, kepraktisan, dan keefektifan media pembelajaran yang dikembangkan adalah sebagai berikut.

Tabel 1. Kriteria Penilaian Kevalidan Media Pembelajaran

\begin{tabular}{cc}
\hline Skor & Kriteria \\
\hline $4,20 \leq n<5,00$ & Sangat tinggi \\
$3,40 \leq n<4,20$ & Tinggi \\
$2,60 \leq n<3,40$ & Sedang \\
$1,80 \leq n<2,60$ & Rendah \\
$1,00 \leq n<1,80$ & Sangat rendah \\
\hline
\end{tabular}

Produk media pembelajaran yang dikembangkan dikatakan valid apabila skor yang diperoleh memenuhi kriteria tinggi.

Tabel 2. Kriteria Penilaian Kepraktisan Media Pembelajaran

\begin{tabular}{cc}
\hline Skor & Kriteria \\
\hline $85 \% \leq \mathrm{P}_{\mathrm{r}}$ & Sangat tinggi \\
$70 \% \leq \mathrm{P}_{\mathrm{r}}<85 \%$ & Tinggi \\
$50 \% \leq \mathrm{P}_{\mathrm{r}}<70 \%$ & Sedang \\
$\mathrm{P}_{\mathrm{r}}<50 \%$ & Rendah \\
\hline
\end{tabular}

Produk media pembelajaran yang dikembangkan dikatakan praktis apabila skor yang diperoleh memenuhi kriteria tinggi.

Tabel 3. Kriteria Penilaian untuk Keefektifan Media Pembelajaran

\begin{tabular}{cc}
\hline Skor Siswa & Kriteria \\
\hline Skor $\geq 70,00$ & Tuntas \\
Skor $<70,00$ & Tidak Tuntas
\end{tabular}

Produk media pembelajaran yang dikembangkan dikatakan efektif apabila $75 \%$ siswa yang mengikuti tes memperoleh skor dalam kriteria tuntas.

\section{Hasil dan Pembahasan}

Pengembangan media pembelajaran matematika berbasis Geogebra dalam penelitian ini menggunakan model pengembangan 4-D. Akan tetapi, karena keterbatasan peneliti, penelitian dilakukan hingga tahap develop (pengembangan). Adapun hasil kegiatan penelitan pengembangan ini adalah sebagai berikut. Pada tahap define (pendefinisian), dilakukan analisis awal melalui wawancara dengan guru kelas XI SMA Negeri 2 Negara. Melalui analisis awal tersebut teridentifikasi empat permasalahan utama siswa dalam proses pembelajaran nilai maksimum dan minimum, yaitu: (1) Siswa belum memahami mengenai munculnya konsep limit ketika menentukan kemiringan garis singgung, (2) Siswa belum memahami alasan mengapa nilai maksimum dan minimum dapat terjadi pada titik-titik kritis suatu fungsi objektif. (3) Siswa kesulitan dalam membentuk pemahaman terkait materi nilai maksimum dan minimum karena tidak adanya media pembelajaran yang dapat membantu siswa dalam bereksplorasi. Media yang tersedia di sekolah hanya terbatas pada penggunaan papan tulis, buku pelajaran, modul, dan slide Power Point.(4) Siswa membutuhkan media pembelajaran yang dapat mendukung pembelajaran mandiri, karena materi pembelajaran di sekolah yang sangat padat tidak dapat disesuaikan dengan kecepatan belajar siswa yang berbeda-beda.

Berdasarkan temuan tersebut, dilakukan analisis mengenai sarana prasarana pendukung untuk pembelajaran nilai maksimum dan minimum di sekolah. Dari analisis ini diketahui bahwa, terdapat komputer dan proyektor LCD yang dapat dimanfaatkan untuk membuat pembelajaran yang lebih eksploratif. Akan tetapi, tidak adanya media 
pembelajaran yang mendukung untuk dapat dieksplorasi oleh siswa menjadi kendala dalam menciptakan proses pembelajaran yang eksploratif tersebut. Oleh karena itu dilakukan kegiatan pengembangan media pembelajaran berbasis Geogebra dengan pendekatan teori van Hiele. Teori van Hiele dipilih karena langkah pembelajarannya disesuaikan dengan tingkat berfikir siswa, sehingga bisa disesuaikan dengan kecepatan belajar siswa yang berbeda-beda. Kelebihan teori van Hieleadalah menyajikan pembelajaran yang sesuai dengan tahap berfikir siswa, sehingga pembelajaran menjadi lebih bermakna dan menghindari penghafalan.Kegiatan penelitian berikutnya adalah analisis kurikulum. Analisis kurikulum dilakukan untuk mengetahui kompetensi inti, kompetensi dasar, dan batasanbatasan materi pembelajaran nilai maksimum dan minimum yang diajarkan di sekolah.

Penelitian pada tahap design (perencanaan) dilakukan pada tanggal 22 April 2018. Pada tahap ini dikembangkan rancang bangun media pembelajaran matematika berbasis Geogebra sesuai dengan hasil analisis awal dan analisis kurikulum. Pada tahap ini juga dilakukan perancangan instrumen penelitian yang digunakan untuk menilai media pembelajaran yang dikembangkan. Sebelum instrumen digunakan untuk menilai media, dilakukan uji validasi isi instrumen untuk memastikan instrumen yang dikembangkan dapat mengukur kualitas media pembelajaran dengan tepat. Adapun hasil validasi isi instrumen yang digunakan dalam penelitian pengembangan ini adalah sebagai berikut.

Tabel 4. Hasil Uji Validasi Isi Instrumen

\begin{tabular}{|c|c|c|c|c|}
\hline \multirow[b]{2}{*}{ Instrumen } & \multicolumn{2}{|c|}{ Penilai I } & \multicolumn{2}{|c|}{ Penilai II } \\
\hline & $\begin{array}{c}\text { Tidak } \\
\text { Relevan }\end{array}$ & Relevan & $\begin{array}{c}\text { Tidak } \\
\text { Relevan }\end{array}$ & Relevan \\
\hline Ahli Media Pembelajaran & - & $\begin{array}{c}\text { Semua } \\
\text { Pernyataan }\end{array}$ & - & $\begin{array}{c}\text { Semua } \\
\text { Pernyataan }\end{array}$ \\
\hline Pengajar & - & $\begin{array}{c}\text { Semua } \\
\text { Pernyataan }\end{array}$ & - & $\begin{array}{c}\text { Semua } \\
\text { Pernyataan }\end{array}$ \\
\hline Instrumen Kepraktisan Guru & - & $\begin{array}{c}\text { Semua } \\
\text { Pernyataan }\end{array}$ & - & $\begin{array}{c}\text { Semua } \\
\text { Pernyataan }\end{array}$ \\
\hline Instrumen Kepraktisan Siswa & - & $\begin{array}{c}\text { Semua } \\
\text { Pernyataan }\end{array}$ & - & $\begin{array}{c}\text { Semua } \\
\text { Pernyataan }\end{array}$ \\
\hline Tes Efektivitas & - & $\begin{array}{c}\text { Semua } \\
\text { Pertanyaan }\end{array}$ & - & $\begin{array}{c}\text { Semua } \\
\text { Pertanyaan }\end{array}$ \\
\hline
\end{tabular}

Pada tahap develop (pengembangan) diperoleh media pembelajaran matematika berbasis Geogebra dengan pendekatan teori van Hiele pada pokok bahasan nilai maksimum dan minimum. Media pembelajaran yang diperoleh disajikan dalam bentuk file file executable (.exe) di dalam sebuah Compact Disk (CD). Adapun beberapa konten yang terdapat dalam media pembelajaran yang dikembangkan, yaitu: konten tamplian awal media, menu utama, materi pembelajaran, contoh soal, contoh permasalahan, informasi tentang pengembang, latihan soal, dan petunjuk penggunaan media. Berikut ini adalah tampilan materi pembelajaran dan masalah sehari hari yang disajikan dalam media pembelajaran yang dikembangkan. 


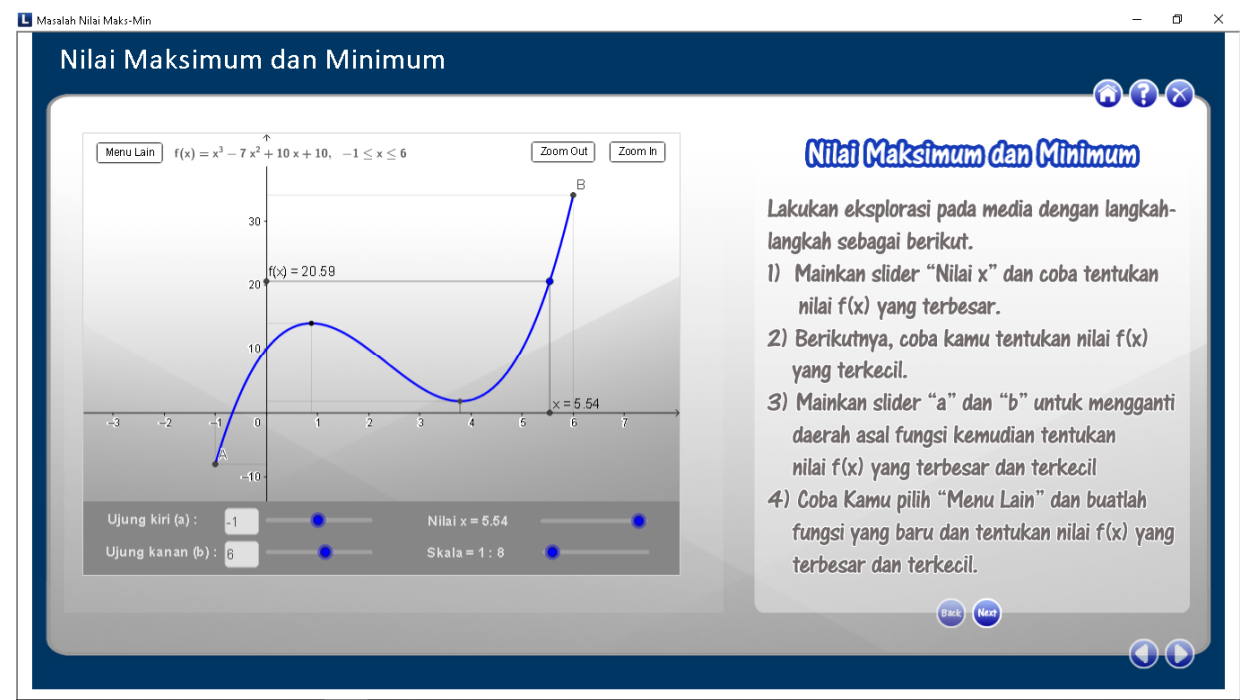

Gambar 1. Tampilan Konten Materi Pembelajaran pada Media

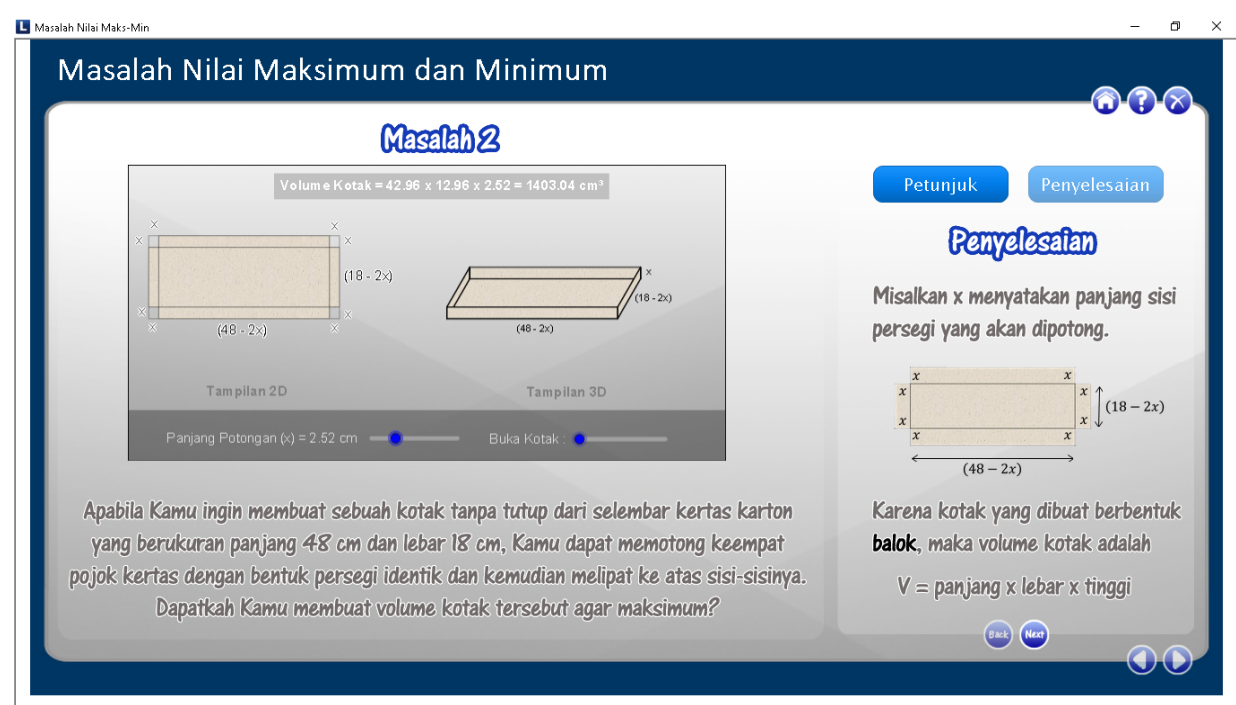

Gambar 2. Tampilan Konten Masalah pada Media

Setelah rancangan produk media pembelajaran selesai, dilakukan penilaian untuk mengetahui kevalidan, kepraktisan, dan keefektifan media pembelajaran yang dikembangkan. Hasil penilaian kevalidan, kepraktisan, dan keefektifan media pembelajaran ditunjukkan oleh Tabel 5,Tabel 6, Tabel 7, Tabel 8,dan Tabel 9 berikut.

Tabel 5. Hasil Uji Validitas oleh Ahli Media Pembelajaran

\begin{tabular}{clccc}
\hline \multirow{2}{*}{ No. } & \multicolumn{1}{c}{ Aspek yang dinilai } & \multicolumn{2}{c}{ Penilai } & \multirow{2}{*}{ Rata-rata } \\
\hline 1 & $\begin{array}{l}\text { Konten disajikan secara utuh tanpa perlu } \\
\text { menggulir (scrolling) }\end{array}$ & 5 & 5 & 5 \\
2 & $\begin{array}{l}\text { Diberikan penjelasan singkat mengenai materi } \\
\text { yang dibahas sebelum memulai pembelajaran }\end{array}$ & 5 & 5 & 5 \\
$3 \quad \begin{array}{l}\text { Kesesuaian pertanyaan dan penugasan } \\
\text { terhadap indikator dan tujuan pembelajaran } \\
\text { untuk memastikan pemahaman siswa }\end{array}$ & 4 & 4 & 4 \\
4 & Kesesuaian latar belakang gambar atau musik & 4 & 4 & 4
\end{tabular}




\begin{tabular}{|c|c|c|c|c|}
\hline \multirow{2}{*}{ No. } & \multirow{2}{*}{ Aspek yang dinilai } & \multicolumn{2}{|c|}{ Penilai } & \multirow{2}{*}{ Rata-rata } \\
\hline & & 1 & II & \\
\hline & \multicolumn{4}{|l|}{ yang digunakan dengan karakteristik siswa } \\
\hline 5 & \multirow{2}{*}{$\begin{array}{l}\text { Media disajikan secara interaktif. } \\
\text { Kemudahan dalam menggunakan media }\end{array}$} & 5 & 4 & 4,5 \\
\hline 6 & & 5 & 5 & 5 \\
\hline 7 & $\begin{array}{l}\text { Kesesuaian ukuran gambar, teks, dan } \\
\text { komponen navigasi. }\end{array}$ & 4 & 5 & 4,5 \\
\hline 8 & $\begin{array}{l}\text { Kesesuaian penggunaan teks dinamis. } \\
\text { Kesesuaian penggunaan teks stasis. }\end{array}$ & 5 & 5 & 5 \\
\hline 9 & \multicolumn{4}{|l|}{ Kesesuaian tampilan pertama (semua } \\
\hline 10 & \multicolumn{4}{|l|}{ tertutup komponen lain). } \\
\hline 11 & \multicolumn{4}{|l|}{$\begin{array}{l}\text { Teks disajikan secara singkat dan jelas. } \\
\text { Kesesuaian banyaknya pertanyaan dan }\end{array}$} \\
\hline 12 & \multicolumn{4}{|l|}{ halaman/slide. } \\
\hline 13 & \multicolumn{3}{|l|}{ Media menggunakan pertanyaan yang spesifik } & 5 \\
\hline 14 & \multicolumn{4}{|l|}{ Kesesuaian teks dalam mendukung komponen } \\
\hline 15 & $\begin{array}{l}\text { Kesesuaian penempatan petunjuk untuk siswa } \\
\text { (petunjuk tidak boleh membingungkan siswa) }\end{array}$ & 4 & 4 & 4 \\
\hline \multirow{2}{*}{\multicolumn{2}{|c|}{$\begin{array}{l}\text { Jumlah skor } \\
\text { Rata-rata skor }\end{array}$}} & 70 & 70 & 70 \\
\hline & & 4,67 & 4,67 & 4,67 \\
\hline
\end{tabular}

Tabel 6. Hasil Uji Validitas oleh Pengajar

\begin{tabular}{|c|c|c|c|c|}
\hline \multirow{2}{*}{ No. } & \multirow{2}{*}{ Aspek yang dinilai } & \multicolumn{2}{|c|}{ Penilai } & \multirow{2}{*}{ Rata-rata } \\
\hline & & 1 & II & \\
\hline 1 & $\begin{array}{l}\text { Keakuratan konten materi dalam mencapai } \\
\text { tujuan pembelajaran }\end{array}$ & 4 & 4 & 4 \\
\hline 2 & $\begin{array}{l}\text { Konten dalam media bebas dari kesalahan } \\
\text { dan disajikan tanpa bias atau penyimpangan } \\
\text { yang dapat menyesatkan siswa }\end{array}$ & 5 & 5 & 5 \\
\hline 3 & $\begin{array}{l}\text { Media menekankan pada poin-poin penting } \\
\text { dan ide-ide penting dari materi pembelajaran }\end{array}$ & 5 & 5 & 5 \\
\hline 4 & $\begin{array}{l}\text { Kesesuaian media dengan karakteristik siswa } \\
\text { (budaya atau etnis) }\end{array}$ & 4 & 4 & 4 \\
\hline 5 & Kejelasan tujuan pembelajaran yang disajikan & 4 & 4 & 4 \\
\hline 6 & $\begin{array}{l}\text { Tujuan pembelajaran sesuai untuk siswa yang } \\
\text { dimaksud }\end{array}$ & 4 & 4 & 4 \\
\hline 7 & $\begin{array}{l}\text { Konsistensi antara tujuan pembelajaran, } \\
\text { kegiatan pembelajaran dan latihan soal }\end{array}$ & 5 & 5 & 5 \\
\hline 8 & $\begin{array}{l}\text { Kesesuaian umpan balik mengenai kualitas } \\
\text { atau ketepatan respon siswa }\end{array}$ & 4 & 4 & 4 \\
\hline 9 & $\begin{array}{l}\text { Relevansi antara konten media dengan minat } \\
\text { pribadi siswa }\end{array}$ & 4 & 4 & 4 \\
\hline 10 & $\begin{array}{l}\text { Kesesuaian tingkat kesulitan dari pertanyaan } \\
\text { atau penugasan yang diberikan untuk } \\
\text { memastikan pemahaman siswa }\end{array}$ & 4 & 4 & 4 \\
\hline \multicolumn{2}{|r|}{ Jumlah skor } & $\begin{array}{c}43 \\
4,30\end{array}$ & $\begin{array}{c}43 \\
4,30\end{array}$ & $\begin{array}{c}43 \\
4,30\end{array}$ \\
\hline
\end{tabular}


Berdasarkan hasil penilaian dari ahli media pembelajaran sebagaimana dicantumkan pada Tabel 5, maka diketahui bahwa rata-rata skor uji validitas oleh ahli media pembelajaran yang dikembangkan adalah 4,67, sehingga diperoleh kriteria validitas ahli media pembelajaran adalah sangat tinggi dan tidak perlu direvisi.Sedangkan, berdasarkan hasil penelitian dari pengajar sebagaimana dicantumkan pada Tabel 6 , diketahui bahwa rata-rata skor validitas oleh pengajar yang dikembangkan adalah 4,30, sehingga diperoleh kriteria validitas oleh pengajar adalah sangat tinggi dan tidak perlu direvisi.

Tabel 7. Hasil Penilaian Kepraktisan Media Pembelajaran oleh Guru

\begin{tabular}{clc}
\hline No. & \multicolumn{1}{c}{ Aspek yang dinilai } & Skor \\
\hline 1 & Media menyajikan tujuan pembelajaran dengan jelas & 4 \\
2 & Media menyajikan soal latihan sesuai dengan materi yang & 4 \\
3 & diajarkan & Media menyajikan umpan balik yang sesuai untuk penguatan \\
4 & Media disajikan secara interaktif & 3 \\
5 & Konten materi yang disajikan tergolong baru dan belum pernah & 4 \\
6 & dibahas sebelumnya. & 4 \\
7 & Media menarik minat dan motivasi siswa untuk belajar & 4 \\
8 & Media pembelajaran tidak tergantung pada bahan ajar lain & 4 \\
9 & Media menyediakan petunjuk penggunaan & 4 \\
10 & Media meminimalisasi penggunaan keyboard & 4 \\
11 & Media meminimalisasi menggulir (scrolling) & 4 \\
Jumlah skor & 4 \\
Rata-rata skor & 43 \\
\hline
\end{tabular}

Tabel 8. Hasil Penilaian Kepraktisan Media Pembelajaran oleh Siswa

\begin{tabular}{clc}
\hline No & \multicolumn{1}{c}{ Aspek yang dinilai } & $\begin{array}{c}\text { Rata-rata } \\
\text { Skor }\end{array}$ \\
\hline 1 & Media menyajikan tujuan pembelajaran dengan jelas & 3,67 \\
2 & $\begin{array}{l}\text { Media menyajikan soal latihan sesuai dengan materi yang } \\
\text { diajarkan }\end{array}$ & 3,78 \\
3 & Media menyajikan umpan balik yang sesuai untuk & 3,33 \\
4 & penguatan & 3,89 \\
5 & Kedia disajikan secara interaktif & 3,33 \\
6 & pernah materi yang disajikan tergolong baru dan belum & 3,67 \\
7 & Media menarik minat dan motivasi siswa untuk belajar & 3,67 \\
8 & Media pembelajaran tidak tergantung pada bahan ajar lain & 3,22 \\
9 & Media menyediakan petunjuk penggunaan & 3,89 \\
10 & Media meminimalisasi penggunaan keyboard & 3,56 \\
11 & Media meminimalisasi menggulir (scrolling) & 3,56 \\
Jumlah skor & 39,56 \\
Rata-rata skor & 3,60 \\
\hline
\end{tabular}

Berdasarkan hasil penilaian kepraktisan media pembelajaran oleh guru yang ditunjukkan pada Tabel 7, diketahui bahwa rata-rata skor penilaian kepraktisan media pembelajaran yang dikembangkan adalah 3,91, sehingga diperoleh kriteria penilaian kepraktisan media pembelajaran oleh guru adalah sebesar $97,75 \%$ yang termasuk kriteria sangat tinggi dan tidak perlu direvisi. Sedangkan, berdasarkan hasil penilaian kepraktisan media pembelajaran oleh siswa yang ditunjukkan pada Tabel 8, diketahui bahwa rata-rata 
skor penilaian kepraktisan media pembelajaran yang dikembangkan adalah 3,60, sehingga diperoleh kriteria penilaian kepraktisan media pembelajaran oleh guru adalah sebesar $90 \%$ yang termasuk kriteria sangat tinggi dan tidak perlu direvisi.

Tabel 9. Hasil Tes Keefektifan Media Pembelajaran

\begin{tabular}{|c|c|c|}
\hline No. & Variasi & Data Kelas Uji Coba \\
\hline 1 & Nilai Tertinggi & 91,67 \\
\hline 2 & Nilai Terendah & 66,67 \\
\hline 3 & Rata-rata & 79,63 \\
\hline 4 & Banyak siswa yang tuntas belajar & 8 \\
\hline 5 & Banyak siswa yang tidak tuntas belajar & 1 \\
\hline 6 & Persentase Ketuntusan & $88,89 \%$ \\
\hline
\end{tabular}

Berdasarkan hasil tes efektifitas yang diberikan kepada 9 peserta uji coba sebagaimana dicantumkan pada Tabel 9, maka diketahui bahwa ketuntasan belajar siswa adalah $88,89 \%$. Persentase ketuntasan belajar siswa ini lebih dari $75 \%$, sehingga diperoleh kriteria bahwa media pembelajaran yang dikembangkan efektif dalam pembelajaran nilai maksimum dan minimum.

Pembahasan mengenai hasil penelitian menunjukkan bahwa media pembelajaran yang dikembangkan memenuhi kriteria valid, praktis, dan efektif dalam pembelajaran nilai maksimum dan minimum. Hasil ini sejalan dengan kajian mengenai hasil penelitian yang relevan yang digunakan dalam penelitian pengembangan ini.

\section{Simpulan dan Saran}

Berdasarkan pembahasan hasil penelitian yang telah diuraikan sebelumnya dapat disimpulkan bahwa hasil penelitian ini adalah sebuah produk media pembelajaran matematika berbasis Geogebra dengan pendekatan teori van Hiele yang mana produk tersebut diberi nama "Media Pembelajaran Nilai Maksimum dan Minimum". Karakteristik media pembelajaran yang dikembangkan adalah menggunakan Geogebra sebagai basis dan Lectora sebagai layout, serta pendekatan teori van Hiele dalam konten materi pembelajarannya. Produk media pembelajaran yang dikembangkan memuat konten tamplian awal media, menu utama, materi pembelajaran, contoh soal, contoh permasalahan, informasi tentang pengembang, latihan soal, dan petunjuk penggunaan media. Untuk memastikan pemahaman konsep siswa, konten materi pembelajaran juga dilengkapi dengan penjelasan, pertanyaan, dan penugasan kepada siswa.

Media pembelajaran yang dikembangkan juga telah di uji coba kevalidan, kepraktisan, dan keefektifannya. Hasil uji coba tersebut menjelaskan bahwa: (1) skor hasil penilaian ahli media pembelajaran adalah sebesar 4,67 dengan kriteria sangat tinggi, (2) skor hasil penilaian oleh pengajar adalah sebesar 4,30 dengan kriteria sangat tinggi, (3) persentase hasil penilaian kepraktisan media pembelajaran oleh guru sebesar 97,75\% dengan kriteria sangat tinggi. (4) persentase hasil penilaian kepraktisan media pembelajaran oleh siswa sebesar $90 \%$ dengan kriteria sangat tinggi, serta (5) hasil tes efektifitas media pembelajaran menunjukkan bahwa persentase ketuntasan belajar siswa adalah 88,89\%. Skor ini menunjukkan bahwa media pembelajaran yang dikembangkan efektif untuk digunakan dalam pembelajaran nilai maksimum dan minimum.

Berdasarkan hasil penelitian ini, produk media pembelajaran matematika berbasis Geogebra dengan pendekatan teori van Hiele yang dikembangkan pada pokok bahasan nilai maksimum dan minimum telah memenuhi kriteria valid, praktis, dan efektif dalam pembelajaran nilai maksimum dan minimum. 
Adapun beberapa saran yang dapat disampaikan dalam penelitian pengembagan ini adalah sebagai berikut. (1) Kepada siswa, sebaiknya media pembelajaran yang dikembangkan tidak hanya dimanfaatkan di sekolah saja. Media telah dirancang untuk mendukung pembelajaran secara mandiri dan dapat dimanfaatkan dimana saja dan kapan saja. Semakin banyak kegiatan eksplorasi yang dilakukan pada media, semakin banyak pemahaman yang dapat diperoleh melalui media pembelajaran ini. (2) Kepada guru, sebaiknya media pembelajaran yang dikembangkan dalam penelitian ini, tidak dioperasikan oleh guru saja. Siswa sebaiknya diberikan kesempatan untuk melakukan eksplorasi secara mandiri. Apabila memungkinkan, guru sebaiknya memberikan masukan atau saran kepada pengembang untuk menyempurnakan media pembelajaran ini. (3) Kepada peneliti lain,sebaiknya media pembelajaran yang dikembangkan dalam penelitian ini, dijadikan sebagai referensi untuk melakukan penelitian pengembangan yang lainnya.

\section{Ucapan Terimakasih}

Dalam proses penyusunan skripsi ini tentu banyak mendapat bimbingan, masukan, arahan, dan saran dari berbagai pihak. Untuk itu, penulis mengucapkan terima kasih yang sebesar-besarnya kepada beberapa pihak sebagai berikut. (1) Prof. Dr. I Nengah Suparta, M.Si., selaku Dekan Fakultas Matematika dan IImu Pengetahuan Alam atas berbagai kebijakannya sehingga studi ini dapat terselesaikan, (2) Dr. Gede Suweken, M.Sc., selaku Ketua Jurusan Pendidikan Matematika sekaligus pembimbing II penulis atas motivasi dan bimbingan yang diberikan dalam penyelesaian skripsi ini. (3) Dr. I Made Sugiarta, M.Si., selaku pembimbing I yang telah memberikan bimbingan, arahan, petunjuk, dan motivasi kepada penulis dalam penyelesaian skripsi ini. (4) Dr. I Nyoman Sukajaya, M.T., selaku penguji II yang telah memberikan bimbingan, arahan, petunjuk, dan motivasi kepada penulis dalam penyelesaian skripsi ini, (5) I Made Suarsana, S.Pd., M.Si. selaku penguji II yang telah memberikan bimbingan, arahan, petunjuk, dan motivasi kepada penulis dalam penyelesaian skripsi ini, (6) Adrianus I Wayan llia Yuda Sukmana, S.Kom., M.Pd., selaku ahli media pembelajaran yang telah memberikan bimbingan, masukan, atau saran dalam penyelesaian skripsi ini, (7) Dr. I Nyoman Gita, M.Si., selaku pengajar dan validator yang telah memberikan bimbingan, masukan, atau saran dalam penyelesaian skripsi ini, (8) I Gede Eri Sastrawan, S.Pd., selaku guru matematika kelas XI SMA Negeri 2 Negara yang telah memberikan bimbingan, masukan, atau saran baik sebagai ahli media, pengajar, ataupun guru dalam penyelesaian skripsi ini,(9) siswa-siswi Kelas XI SMA Negeri 2 Negara, atas semua kerjasamanya selama penelitian, dan semua pihak yang turut dalam proses membantu penyelesaian skripsi ini.

\section{Daftar Pustaka}

Abdussakir. 2009. "Pembelajaran Geometri Sesuai Teori van Hiele", Volume 11, Nomor 1 (hlm. 1-13).

Anne, T.. 1999. "The van Hiele Models of Geometric Thought". Tersedia pada http://euler.slu.edu/teach_material/van_hiele_model_of_geometry.html, (diakses tanggal 20 April 2018).

Candiasa, I. M. 2010. Statistik Univariat dan Bivariat Disertai Aplikasi SPSS. Singaraja: Undiksha Press.

Hohenwarter, J. dkk. 2008. "Introducing Dynamic Mathematics Software to Secondary School Teachers: The Case of Geogebra". Journal of Computers in Mathematics and Science Teaching(2008), Volume 28, Nomor 2 (hlm. 135-146)

Hohenwarter, M. dan Fuchs, K. (2004). "Combination of Dynamic Geometry, Algebra, and Calculus ini the Software System Geogebra", Tersedia pada www.Geogebra.org/publications/pecs_2004.pdf. (diakses pada tanggal 15 April 2018).

Hohenwarter, M. dan Lavicza. 2007. "Mathematics Teacher Development with ICT: Towards an International Geogebra Institute". Dalam Kuchemann, D., editor, Proceedings of the 
British Society for Research into Learning Mathematics, Volume 27, Nomor 3 (hlm. 4954).

Hohenwarter, M. dkk. 2008. "Teaching and Learning Calculus with Free Dynamic Mathematics Software Geogebra". Tersedia pada http://www.publications.uni.lu/record/2718/files/ICME11-TSG16.pdf. (diakses pada tanggal 15 April 2018 ). 